\title{
PROGRESS REPORT ON 'GRASSLANDS 4700' WHITE CLOVER
}

\author{
w. C. Weeda, N. A. Cullen, J. A. Douglas, and C. During \\ Research Division, Department of A griculture \\ Ruakura and Invermay
}

THIS REPORT summarizes the results of comparisons of 4700 and Huia white clovers carried out by the Department of Agriculture in the past two to three years. Contributions come from the Field Research Section which conducts experiments on a New Zealandwide basis, and from the Invermay and Ruakura Research Centres, representing coastal Otago and the Waikato, respectively.

\section{RUAKURA}

It was thought that a strain with a relatively open growth habit and a high potential for winter production (4700) might be more susceptible to close grazing and trampling in winter than a strain of clover relatively dormant in winter (Huia) . This hypothesis is being'tested using sheep in small paddocks on a soil kept at fairly high mineral fertility.

Approximately 3 acres were fallowed from spring 1964 onwards, subdivided into 32 paddocks, 16 of each being sown to either 4700 or Huia, and Ariki, in March 1966. Pasture growth was estimated by frames using a recovery-after-trimming technique.

Heavily stocked treatments carried 14 dry sheep per acre from about mid-June to nearly the end of September, with lightly stocked paddocks at 7 sheep per acre. In the first year, the light stocking rate had to be reduced at times. The rotation was 1 day's grazing in every 8 days in the first winter and 2 consecutive days' grazing in every 16 days in subsequent winters. All paddocks were then brought to about equal amount of standing pasture by spelling the hard-grazed treatments; thereafter all were rotationally grazed at the same stocking rate until next winter. 


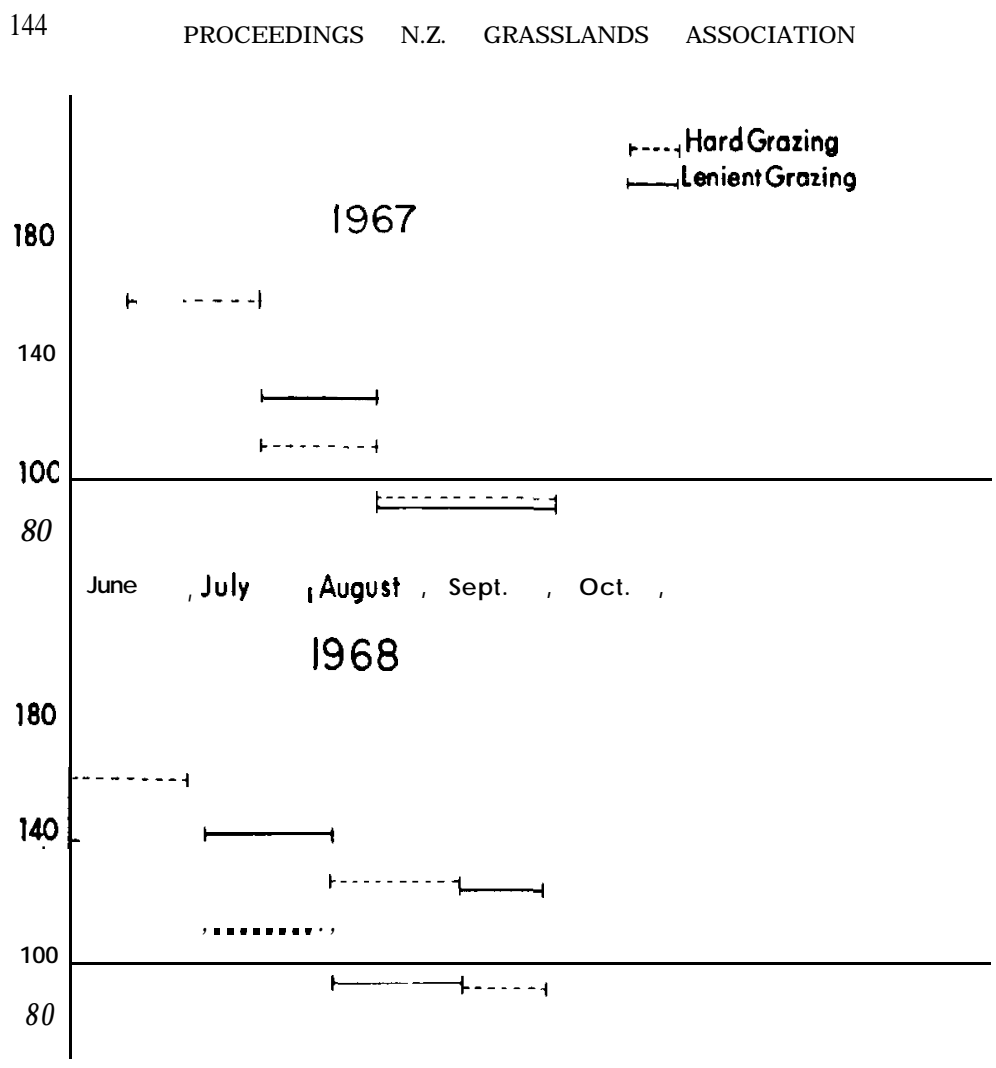

FIG. 1: Relative yields of 4700 compared with Huia $=100$.

TABLE 1: MEAN ANNUAL YIELDS OF PASTURE, 1967.9 (lb D.M. per acre)

\begin{tabular}{|c|c|c|c|c|c|c|c|}
\hline \multirow{2}{*}{\multicolumn{4}{|c|}{ Grazing }} & \multicolumn{2}{|c|}{ Huia } & \multicolumn{2}{|c|}{4700} \\
\hline & & & & Total & Clover & Total & Clover \\
\hline Lenient & . & & & 13,640 & 4,580 & 13,890 & 5,380 \\
\hline Hard & & $\ldots$ & $\ldots$ & 13,420 & 4,480 & 13,560 & 4,840 \\
\hline Difference & & $\ldots$ & & 220 & 100 & 330 & 540 \\
\hline & $\ldots$ & $\ldots$ & & 1.6 & 2.2 & 2.4 & 10.0 \\
\hline
\end{tabular}

Mean winter yields (Jun.-Oct. 1967 and 1968)

\begin{tabular}{|c|c|c|c|c|c|c|c|}
\hline Lenient & & $\cdot$ & & 4,920 & 1,290 & 5,030 & 1,440 \\
\hline Hard & . & $\ldots$ & . & 4,280 & 1,120 & 4,380 & 1,160 \\
\hline Difference & & $\ldots$ & $\ldots$ & 640 & 170 & 650 & 280 \\
\hline$\%$ & $\therefore$ & & $\ldots$ & 13.0 & 13.2 & 12.9 & 19.4 \\
\hline
\end{tabular}


TABLE 3: PRODUCTION, TRIAL 2, HINDON (lb D.M. per acre)

\begin{tabular}{|c|c|c|c|c|c|c|c|c|c|c|c|}
\hline & $25 / 10 / 67$ & $18 / 12 / 67$ & $\begin{array}{l}1967.8 \\
8 / 2 / 68\end{array}$ & $10 / 5 / 68$ & Year & $6 / 11 / 68$ & $11 / 12 / 68$ & $\begin{array}{r}1968 \\
16 / 1 / 69\end{array}$ & ${ }^{9} 26 / 3 / 69$ & $9 / 5 / 69$ & Year \\
\hline \multicolumn{12}{|c|}{ Total production } \\
\hline Huia & $1,460 \mathrm{a}$ & $2,700 \mathrm{aA}$ & $870 \mathrm{a}$ & $1,130 \mathrm{a}$ & $6,160 \mathrm{a}$ & $1,810 \mathrm{aA}$ & $1,910 \mathrm{aA}$ & $1,220 \mathrm{a}$ & $310 \mathrm{bB}$ & $320 a$ & $5,570 \mathrm{a}$ \\
\hline $\begin{array}{l}4700 \\
\mathrm{c} v \%\end{array}$ & $1,430 \mathrm{a}$ & $2,300 \mathrm{bB}$ & $860 \mathrm{a}$ & $1,230 \mathrm{a}$ & $5,820 a$ & $1,510 \mathrm{bB}$ & $1,780 \mathrm{bB}$ & $1,250 \mathrm{a}$ & 460aA & $370 \mathrm{a}$ & $5,370 \mathrm{a}$ \\
\hline $\mathrm{c} \mathrm{v} \%$ & 24.7 & & & & 13.9 & & & 9.6 & 20.7 & 22.2 & \\
\hline \multicolumn{12}{|c|}{ Clover production } \\
\hline Huia & $440 \mathrm{a}$ & $1,350 \mathrm{a} A$ & $640 \mathrm{a}$ & 660 & 3,090 & 1,180 & 1,400 & 960 & $210 \mathrm{bB}$ & $200 \mathrm{bB}$ & 3,950 \\
\hline 4700 & $410 \mathrm{a}$ & $970 \mathrm{bB}$ & В 650a & 760 & $\begin{array}{r}2,790 \\
\end{array}$ & 980 & 1,280 & 940 & $340 \mathrm{aA}$ & $270 \mathrm{aA}$ & 3,810 \\
\hline c v $\%$ & 45.0 & 29.9 & 19.4 & NA & NA & NA & N A & NA & 29.6 & 24.9 & NA \\
\hline
\end{tabular}


RESULTS

Some of the results are shown in Table 1 and Fig. 1.

The 4700 white clover, while more sensitive to winter grazing treatments than Huia, even when hard grazed produces as much as the latter. In early winter it produced appreciably more dry matter than the Huia as shown in Fig, 1, and over the whole year the mean yield of 4700 tended to be higher than that of Huia from the beginning of March to November, without being clearly inferior to Huia in mid-summer (not shown),

There is also the possibility that in mid-winter total yields of 4700-based pastures will be significantly higher than those of Huiabased pasture.

\section{INVERMAY}

The performance of 4700 white clover is being studied in two trials on high-fertility soil at Invertnay Research Station and in two trials on low-fertility soil near Hindon.

Two mowing trials sown in February 1967 include two rates ( 5 and $20 \mathrm{lb} . /$ acre) of Ruanui and Ariki ryegrass sown with $3 \mathrm{lb} / \mathrm{acre}$ white clover. In the other trials the performance of the two clovers is being recorded under sheep grazing.

Germination, plant density and yield data were collected.

\section{RESULTS}

Results followed a similar pattern in all trials. During establishment, 4700 clover proved inferior to Huia in herbage density and dry matter production. Germination counts showed that the number of clover plants was similar in both treatments and hence the lower clover density in the 4700 plots appeared to result from its poorer "tillering" habit rather than from fewer plants being present or poorer growth of the plants.

TABLE 2; CLOVER DENSITY

(Total hits per 100 points)

\begin{tabular}{|c|c|c|c|c|c|c|}
\hline & \multicolumn{3}{|c|}{ Trial 1 In vigh Fertility) } & \multicolumn{3}{|c|}{$\begin{array}{c}\text { Trial } 2 \text { (Low Fertility) } \\
\text { Hindon }\end{array}$} \\
\hline & $26 / 9 / 67$ & $3 / 4 / 68$ & $16 / 12 / 68$ & $26 / 9 / 67$ & $23 / 3 / 68$ & $20 / 11 / 68$ \\
\hline $\begin{array}{l}\text { Huia } \\
4700 \\
\text { CV \% }\end{array}$ & $\begin{array}{c}18 \mathrm{aA} \\
10 \mathrm{bB} \\
36.3\end{array}$ & $\begin{array}{l}47 \\
47 \\
-\end{array}$ & $\begin{array}{l}68 \\
68 \\
-\end{array}$ & $\begin{array}{l}40 \mathrm{aA} \\
31 \mathrm{bA} \\
27.4\end{array}$ & $\begin{array}{c}69 \mathrm{aA} \\
52 \mathrm{bB} \\
16.8\end{array}$ & $\begin{array}{l}86 \mathrm{aA} \\
69 \mathrm{bB} \\
14.5\end{array}$ \\
\hline
\end{tabular}

Figures are means of ryegrass treatments. 
The lower density in the 4700 treatments was most noticeable during the spring following establishment but was still evident in the trial on the low-fertility site in the second spring, although differences in density were no longer present on the high-fertility soil (Table 2).

The herbage yields generally followed the pattern shown in Table 3. In the first season both the clover and total herbage yields were significantly higher in the Huia treatments in late spring but the opposite situation occurred in autumn. However, the extra herbage produced by 4700 clover in autumn and winter failed to offset the lower spring and early summer production in that treatment. In the second year, the performance of 4700 relative to Huia improved, particularly in the high-fertility trial at Invermay where total herbage production was significantly higher in the 4700 treatment in early spring, autumn and yearly totals. Huia clover was not superior to 4700 at any cut in the Invermay trial in the second season.

Two years' data from the grazing trial at Invermay indicated that 4700 clover could not withstand close sheep grazing as well as Huia, and clover yields were significantly lower in this treatment in beth seasons.

\section{FIELD RESEARCH}

The trials quoted were sown mostly in autumn 1967 so that results can only be regarded as interim. All possible care was taken to obtain sites likely to be low in Huia-type hard seed. One trial - Tauranga - is grazed, the other 5 trials are conducted under ,a mowing and clippings-returned technique (Lynch, 1947) .

\section{RESULTS}

In the first year, the yield of pastures based on 4700 white clover (4700 pastures) and yield of 4700 white clover itself (4700) tended to be inferior to the yield of Huia-based pastures (Huia pastures) and of Huia white clover itself (Huia) (Table 4).

However, in the second year these initial effects had disap peared and 4700 clover lived up to its promise of relatively high production in winter and 4700 yielded more highly than Huia as far south as Timaru (Table 5). At Timaru, however, winter growth was measured from May 13 to September 171968 , with much of the rather good yield accumu- 
TABLE 4: YIELDS OF DISSECTED CLOVERS AND OF PASTURE IN $1967-8$

(lb D.M. per acre)

\begin{tabular}{|c|c|c|c|c|}
\hline \multirow[b]{2}{*}{ Site } & \multicolumn{2}{|c|}{ Pasture } & \multicolumn{2}{|c|}{ Dissëcted Clover } \\
\hline & Huia & 47 oo.f & Huia & $4700+$ \\
\hline Dargaville & 6,360 & $4.9 *$ & 1,210 & $-12.4 \mathrm{NA}$ \\
\hline Tauranga & 10,300 & $-13.3 \mathrm{NA}$ & 1,180 & - $17.0 \mathrm{NA}$ \\
\hline Takapau & 4,900 & $=$ & 410 & -9.8 \\
\hline Masterton & 8,490 & $=$ & 2,090 & +10.0 \\
\hline Timaru & 8,570 & $=$ & 2,850 & $+9.0^{* *}$ \\
\hline Invercargill & 8,270 & $-15.2^{* *}$ & \multicolumn{2}{|c|}{ no data } \\
\hline
\end{tabular}

*Significance at $5 \%$ level. * Significance at $1 \%$ level. NA Not analysed.

TABLE 5: YIELDS IN WINTER 1968

(lb D.M. per acre)

\begin{tabular}{|c|c|c|c|c|}
\hline Site & Huia & $\begin{array}{l}\text { Pasture } \\
\quad 4700 \dagger\end{array}$ & $\begin{array}{l}\text { Dissected } \\
\text { Hui a }\end{array}$ & $\begin{array}{l}\text { Clover } \\
4700+\end{array}$ \\
\hline Dargaville & 830 & $+9.6^{*}$ & 20 & $+400 \mathrm{NA}$ \\
\hline Tauranga & 1,500 & - $9.3 \mathrm{NA}$ & 180 & $+105 \mathrm{NA}$ \\
\hline Takapau & 180 & +11.0 & 20 & $+100^{*}$ \\
\hline Masterton & 1,470 & - 5.4 & 290 & $+17,2^{* *}$ \\
\hline Timaru & 770 & $+31.0^{* k}$ & 530 & $+43.4^{* *}$ \\
\hline Invercargill & 680 & $=$ & 230 & $=$ \\
\hline
\end{tabular}

*Significance at $5 \%$ level. **Significance at $1 \%$ level.

NA Not analysed.

$=$ Difference $3 \%$ or less.

+ - Better $\%$, - worse $\%$.

$=$ Difference $3 \%$ or less.

$\dagger+$ Better $\%,-$ worse $\%$.

TABLE 6: YIELDS FOR YEAR 1968-9

(lb D.M. per acre)

\begin{tabular}{|c|c|c|c|c|}
\hline Site & Huia & $\begin{array}{l}\text { ture } \\
\qquad 4700^{+}\end{array}$ & $\begin{array}{l}\text { Dissected } \\
\text { Huia }\end{array}$ & $\begin{array}{l}\text { Clover } \\
4700{ }^{4}\end{array}$ \\
\hline Dargaville & 7,400 & $+10.1^{* *}$ & 940 & $+76.5 \mathrm{NA}$ \\
\hline Tauranga & 12,050 & $=$ & 3,420 & $+32.8 \mathrm{NA}$ \\
\hline Takapau & 8,040 & $=$ & 3,630 & $=4.4$ \\
\hline Masterton & 9,340 & $=$ & 3,490 & $+14.4^{*}$ \\
\hline Timaru & 4,570 & $=$ & 3,080 & $=$ \\
\hline Invercargill & 7,550 & -4.2 & 3,110 & $=$ \\
\hline
\end{tabular}

**Significance at $1 \%$ level,

NA Not analysed.

$=$ Difference $3 \%$ or less.

++ Better \%,-worse \%. 
lating in the last fortnight of this period. Also at Timaru clovers represented an atypical $70 \%$ of the total yield and hence markedly influenced this yield. But total annual yield of 4700 pasture was not affected by this because Huia pasture produced more than the former in mid-spring. Thus the results obtained at Timaru are agreeably consistent with the results obtained at Invermay. The only other site on which 4700 pasture was superior to Huia pasture in winter was at Dargaville.

Yields for the whole year 1968-9 are shown in Table 6. In the northern part of the North Island and in the trial at Masterton, 4700 produces more highly than Huia but only at Dargaville are 4700 pastures superior in yield to Huia pastures.

\section{DISCUSSION}

There is evidence that 4700 "establishes" itself more slowly than Huia. Invermay data suggest that this is due to low initial vigour of tillering, and also that speed of tillering is more strongly influenced by soil fertility in 4700 than in Huia. After the establishment period, it is clear that in the warmest parts of New Zealand 4700 pasture promises to produce slightly more than Huia pasture in winter and in Northland perhaps for the whole year.

What evidence there is suggests that in mid-New Zealand, namely, the southern part of North Island, pasture production is little affected by the two clover species although 4700 grows better in winter than Huia. In South Canterbury and mid-Otago where growth in mid-winter is very slow, 4700 pastures appear to yield more than Huia pastures in autumn and very early spring, and less in mid-spring. Thus, there is no total increase but a redistribution of production. Possibly, however, this beneficial result is obtained only with high soil fertility. In Southland, so far no advantage could be seen from the use of 4700 .

Observations to date suggest that changes in latitude, and perhaps rainfall incidence, have in some ways an unexpected influence on the relative performance of Huia and 4700 pastures and that soil fertility may play an important part in this relationship. There is little doubt that the effects of competition between clovers and a sward of mixed grasses needs to be studied in more detail, particularly with regard to the precise period over which 4700 grows faster than Huia. Equally, or more important, may be a critical study of soil fertility factors, of $\mathrm{P}, \mathrm{K}, \mathrm{S}, \mathrm{pH}$, Mo, and of the influence of nitrogen on the relative performance of these clovers and, conversely, the relative influence of these clovers on nitrogen status of pastures. 


\section{ACKNOWLEDGEMENTS}

The report of the Field Research Section is based on results of trials conducted by G. J. Goold, T. F. Southon, A. Thompson, G. Croughley, C. C. McLeod and J. T. Witchalls. I. R. McDonald assisted with trials at Invermay.

Thanks are also due to herbage dissection staff for a very large volume of work.

\section{REFERENCE}

Lynch, P. B., 1947: N.Z. Il Sci. Technol, A28: 385-405.

\section{JOINT DISCUSSION}

White expressed disappointment with the performance of 4700 white clover and suggested that a careful evaluation of the programme should be made before more money was spent on testing. Corkill pointed out that all speakers had stressed that the report was only an interim one. It was the policy of Grasslands Division that no variety would be released until it had shown superiority to another. He felt that 4700 had shown sufficient superiority, particularly in the North Island, to warrant further trials and so it had been decided to produce more seed for this purpose. The decision on whether or not to release the variety would be made only after full consideration by the Department of Agriculture and Grasslands Division of its performance in a wide range of trials.

Barclay stated that, in single plant trials at Lincoln, 4700 had given greater winter but less summer growth. It would be better if the greater winter production were matched by increased summer growth. Trials at Kaikohe, Ruakura and Palmerston North had indicated a degree of success and there was little trouble with establishment with these trials. There were clearly establishment problems in the South Island - e.g., only $10 \%$ white clover (Huia and 4700) in the first year at Lincoln. Establishment was poor also in more southern trials. It could well be that changes in management would help. There had been difficulty experienced in the early testing of Ariki ryegrass because of poor establishment of grass and clover. Sears had shown how to overcome that by management. Similarly with Tama, where late sowing affected establishment, good results were obtained by earlier sowings. It was possible that lenient management in the spring would assist and also that the plant breeder might be able to select for plants with stronger stolons.

Cullen pointed out that, under high-fertility conditions, 4700 was becoming progressively better year after year. It did appear that in most areas Huia became superior to 4700 in late spring though Harris maintained that this happened in September at Gore.

To a suggestion that nitrogenous fertilizers might be an advantage in South Island, Vartha stated that none had been used in the Lincoln trials. It had been noticed that in the first winter, which was very cold, only 
3001b D.M. had been produced while in the second, much warmer winter, D.M. production increased to $1,300 \mathrm{lb}$. He felt that 4700 did have potential, but that establishment was important. This, in turn, required good management.

Wilson reported that a trial was being carried out at Massey University No. 2 Dairy Unit, comparing pure swards of Huia and 4700 white clovers. These were being grazed with lactating cows and involved short-term experiments with identical twin cows at different times of the year. There had been no difference in either milk yield or milk composition. Bloat had occurred on both pastures with no difference in frequency or intensity.

In reply to a question concerning which ryegrass would be most suitable to sow with 4700, Barclay said trials were being carried out at Palmerston North using both Ariki and Manawa. Douglas reported that, at Tauranga, trials had been sown at two rates with Ruanui, Ariki, and Manawa. So far there had been no interactions with the various ryegrasses and clover. Harris stated that at Gore production from 4700, in the third year, was highest with thinned-out Manawa and lowest with Ariki. 